\title{
.
}

DOI: 10.1515/plass-2017-0022

Bogdan Flis

Plant Breeding and Acclimatization Institute - National Research Institute, Młochów Research Center, Platanowa Str. 19, 05-831 Młochów, Poland e-mail: b.flis@ihar.edu.pl

\section{SELECTION OF POTATO PARENTAL LINES WITH COMPLEX RESISTANCES TO POTATO PATHOGENS AND PESTS}

\begin{abstract}
The efficiency of breeding new potato cultivars may be increased by pre-breeding that is by developing parental lines, which have new traits, not present in the genetic pool available for breeders or have new combinations of genes, or have improved level of economically important traits. The use of parental lines in commercial breeding programs is expected to ensure the biological progress in the newly created cultivars of potato. At the beginning, the development of parental lines in Młochów Research Center of Plant Breeding and Acclimatization Institute - National Research Institute (IHAR-PIB) was focused on resistance to viruses and later on resistance to late blight and other pathogens. The procedures of selecting resistant parental lines are described. These procedures were initially based on purely phenotypic tests for resistance, which lately were supplemented with marker assisted selection (MAS) applying molecular markers linked with some resistance genes.
\end{abstract}

Key words: Globodera rostochiensis Ro1, Phytophthora infestans, pre-breeding, marker assisted selection, PVX, PVY, PVM, PVS,

\section{INTRODUCTION}

The efficiency of breeding new potato cultivars may be increased by prebreeding that is by developing parental lines. These lines have improved level of target traits or have introduced new traits, which are not present in the genetic pool available for breeders, or have new combinations of genes (traits). Usually, the genetic sources of new traits cannot be directly used in commercial breeding, same as methods or techniques used for their identification, introduction or testing. The use of parental lines in commercial breeding programs is expected to ensure the breeding progress in the newly created cultivars of potato. The idea of supporting breeding through the production of parental forms has been realized by many research

Communicated by Ewa Zimnoch-Guzowska 
centers worldwide (Proceedings of EAPR/Eucarpia Conference, 1988). In the case of the large breeding companies, such pre-breeding activities are usually performed by their own research departments.

Parental lines have been developed in Młochów Research Center of Plant Breeding and Acclimatization Institute - National Research Institute (IHAR-PIB) from 1970s and have been successively transferred to potato breeding stations in Poland (Swieżyński and Zimnoch-Guzowska, 1996). These lines were donors of resistance traits, having the genetic background enriched with genes originating from various Solanum species. This pre-breeding program has been developed on both tetraploid and diploid levels. Newly recognized variation is transferred from diploid to tetraploid level with the use of $2 n$ gametes phenomenon in selected diploids. In the 5year cycles of pre-breeding, parental lines are selected for resistances to main potato viruses, late blight in foliage and tubers, potato cyst nematodes, wart, soft rot as well as for agronomic and quality traits. Initially, the resistances to various viruses were predominant in parental lines in order to support breeding potato cultivars, which were to be easier for seed industry, thanks to low or no virus infection during their reproduction. In the last four decades, the parental lines have been developed, which were resistant to an increasing number of main potato viruses (ZimnochGuzowska et al., 2013). At first, the parental lines were resistant to potato virus $Y$ (PVY) and potato virus $X(\mathrm{PVX})$, and then these resistances were combined with resistances to potato leafroll virus (PLRV), potato virus $M$ (PVM) and potato virus $S$ (PVS). The resistances to most of these viruses are based on mechanism of localization of infection, which is controlled by dominant genes, like extreme resistances to PVY and PVX, and hypersensitive resistances to PVM and PVS (reviewed by Valkonen, 1994). In the cases of PLRV and PVM, two other types of resistance were found. The first one operates against multiplication and accumulation of virus and is also controlled by major gene or genes (for PLRV reference Flis and Wasilewicz-Flis, 1998; for PVM reference Świeżyński et al., 1980), while the second type of resistance protects against infection by aphid transmitting PLRV and is under complex genetic control (Davidson, 1973).

To achieve the aims in this short term scheme of pre-breeding, it was assumed that the applied selection pressure should be very high and this was done by applying extensive testing of breeding materials for various complexes of resistances. The rapid multiplication of plant material was necessary to provide material for these tests (for example, each selection cycle began with seedlings grown in the field, which produce much more tubers than those growing in the greenhouse). Furthermore, the selection was not limited to resistance traits, but the traits determining the use of the future cultivar (as table, starch, for processing or suitable for growing on dry and light soils) were also taken into account. In total, from parental lines developed in Młochów Research Center, 71 cultivars were released, from which 35 were starch cultivars.

\section{PHENOTYPIC SELECTION}

The scheme of phenotypic selection is presented in Fig. 1. The table shows the approximate numbers of breeding lines in each stage of the selection (of vegetative progeny of seedling). The use of this scheme for over 40 years al- 
lowed obtaining and delivering to breeders 284 parental lines. From their progenies 71 potato cultivars were selected by Polish breeding companies.

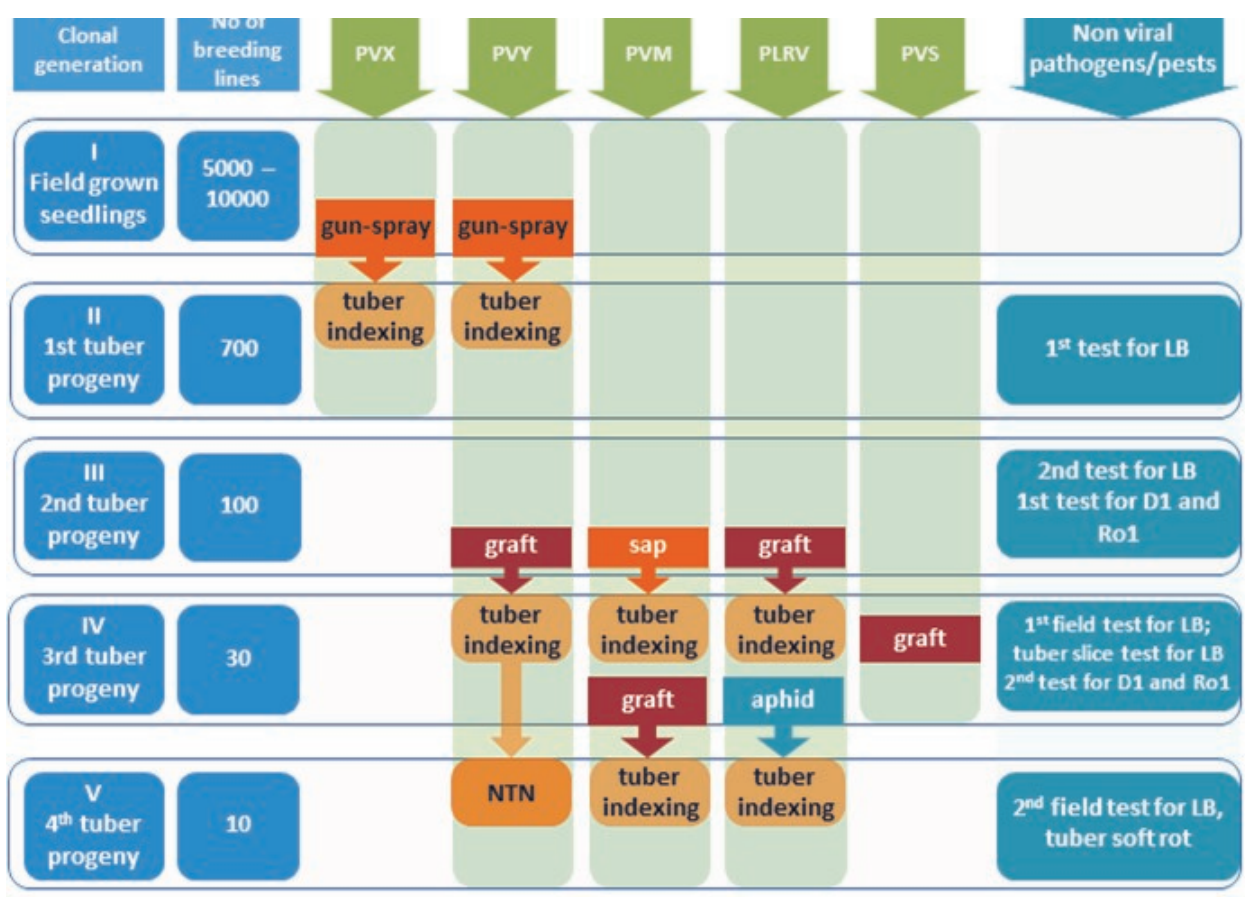

Fig. 1. Phenotypic selection of parental lines for resistance to viral and non-viral pathogens or pests. Inoculations with viruses were done by infectious sap (gun-spray or sap) or by grafting with scions from infected tobacco, tomato or potato plants (graft) or by using infectious aphids (aphid).

Abbreviations:

$\mathbf{I}-\mathbf{V}$ - year in the selection scheme;

LB - testing resistance to Phytophthora infestans, agent of late blight;

D1 - testing for common pathotype D1 of Synchytrium endobioticum, agent of potato wart;

Rol - testing for resistance to pathotype Rol of golden nematode Globodera rostochiensis;

Soft rot - testing for resistance to bacteria Pectobacterium ssp.;

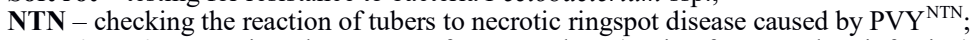

tuber indexing - testing plants grown from eye plugs (testing for secondary infection).

The selection of genotypes resistant to PVX and/or PVY started as early as at the stage of very young seedlings. The seedlings were sprayed with inoculums of PVY and/or PVX with a spray gun (Wiersema, 1972). After 3 weeks, symptomless seedlings were transplanted into pots and then into field. The method was also applied in the case of preliminary screening for resistance to PVM.

Further screenings for resistance to various viruses were based on applying artificial inoculations by grafting with infectious scions or by mechanical inoculation with sap from infected plants. In each case, the tuber progeny of inoculated plants was tested for the presence of the virus. The viruses were detected by ELISA.

The final test for extreme resistance to PVY was performed by grafting potato plants with tobacco scions infected with the virus isolate from necrotic strain of PVY (Zimnoch-Guzowska et al., 2013). The presence of the virus in plants was 
determined on the basis of serological test (ELISA) both in inoculated plants and in their tuber progeny. The graft inoculation was the only method for the screening for the resistance to PVS. In this case the necrotic reaction on axillary lateral shoots below graft union was the indicator of the resistance to this virus (Marczewski et al., 1998).

The screening for resistance to PVM had two stages and the first one was sap inoculation. The plants, which remained uninfected in this stage, were subjected to the second test, which was the graft inoculation. In each of these stages, infection was tested twice, that is after inoculation and in plants of tuber progeny. Details of inoculation, ways of keeping the infected plants, and the dates of their testing for the virus presence are given by Chrzanowska et al., (2002).

For screening of genotypes resistant to multiplication and accumulation of PLRV, the graft inoculation was also applied. Evaluations of virus presence with ELISA were done in axillary lateral shoots developed below the graft union, in etiolated sprouts from tubers of inoculated plants - the method of testing was described by Syller (1988) and in the tuber progeny plants as described by Flis and Wasilewicz-Flis (1998). At final stage of breeding cycle, the aphid inoculation in greenhouse conditions was applied to assess resistance to multiplication of PLRV as well as resistance to infection (Chuquillanqui and Jones, 1980; Syller, 1987).

An important feature of pre-breeding program in Młochów Research Center was that breeding lines were exposed to a natural high virus infection pressure in experimental field and assessed for virus infection by ELISA in tuber indexing.

Development of breeding lines resistant to Phytophthora infestans, the causal agent of late blight, was among the main aims of pre-breeding in Młochów Research Center. The screening for resistance was done on the basis of laboratory tests, which are detached leaflet test and tuber slices test, sometimes supplemented by whole tuber test. The detached leaflet test was described by Plich et al., (2016, 2017) and Brylińska and Śliwka (2017), and test for resistance in tubers slices was described by Zarzycka (1990) and Brylińska and Śliwka (2017).

Tests for resistance to Synchytrium endobioticum and nematode Globodera rostochiensis and bacteria causing soft rot of tubers were carried out mainly in order to add valuable characteristics of the derived parental lines, although for a certain time, the breeding lines resistant to nematodes or Pectobacterium were bred within separate programs in Młochów Research Center. The tests for resistance to S. endobioticum and nematodes were carried out in certified laboratory. Tests for resistance to nematodes were done in accordance with the procedure EPPO (EPPO/ OEPP Bulletin 2006). The resistance to S. endobioticum is tested accordingly to method of Glynne-Lemmerzahl, but with some changes in scale used to evaluate disease development (Przetakiewicz, 2009; Przetakiewicz and Plich, 2017) Tests for resistance to Pectobacterium were performed in the last stage of selection and were done using artificial inoculation of tubers as described by Lebecka (2017).

\section{MIXED PHENOTYPIC AND MARKER ASSISTED SELECTION}

The progress in molecular genetics resulted in the development of molecular markers, which are linked to traits or genes of interest. Such molecular markers linked to the resistance genes enable selection based on the genotype, and thus independent of 
environmental factors influencing the evaluated resistance. The use of a molecular marker does not impose any requirements on the number of the tested plants or tubers, therefore, such markers may be identified at any stage of the selection.

Molecular markers for genes controlling resistance to viruses and $P$. infestans and applied in pre-breeding were identified in Młochów Research Center. The scheme of marker assisted selection for some pathogens is presented in Fig. 2. Footnote to this table includes references to papers with details of applied markers. The reference on the use of markers linked with the gene $H 1$ conferring resistance to G. rostochiensis pathotypes Rol and Ro4 includes also information on stage of breeding scheme, which is the most suitable for applying of such marker. In the Photo 1 the typical visualization of molecular marker linked to the resistant gene $\mathrm{Hl}$ is presented.

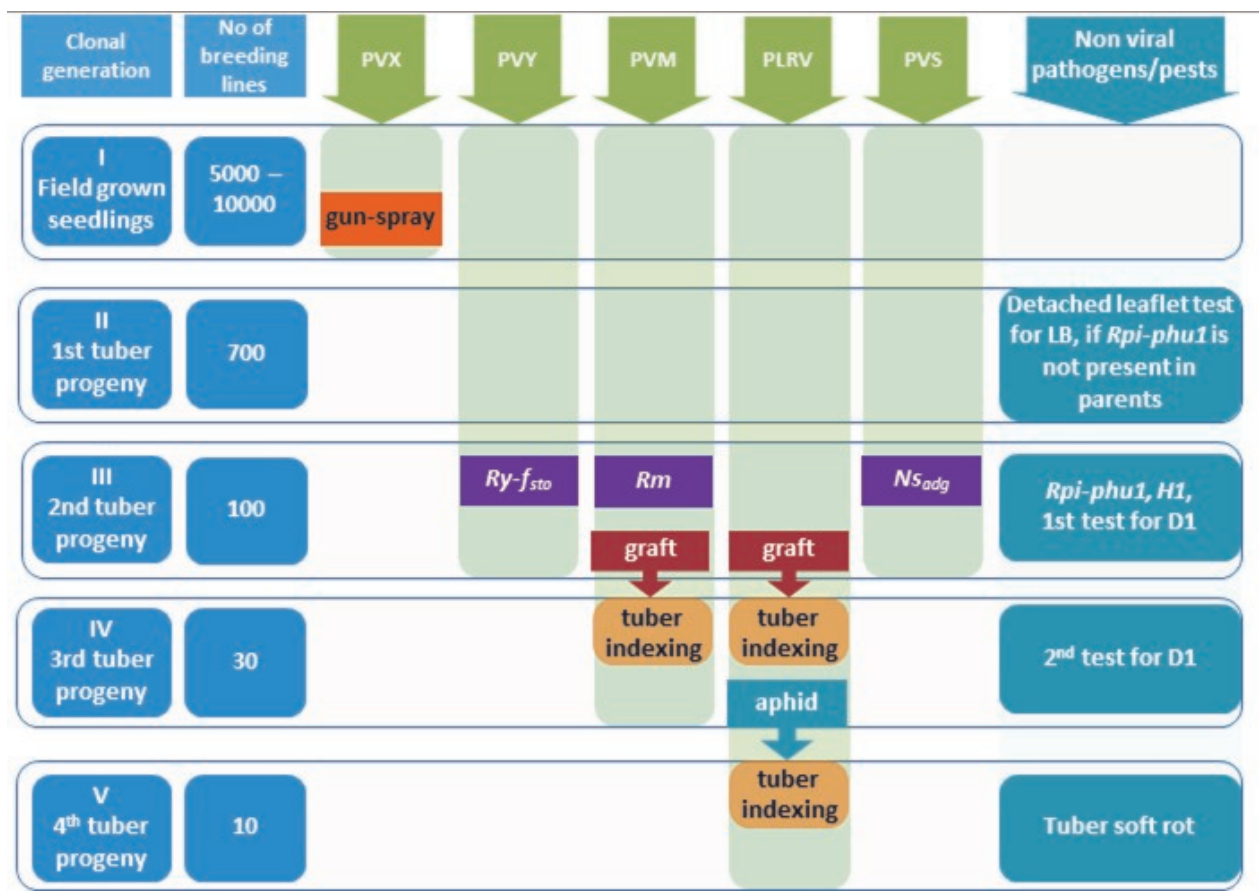

Fig. 2. Mixed phenotypic and marker assisted selection (MAS - in the $2^{\text {nd }}$ tuber progeny clones) of parental lines for resistance to viral and non-viral pathogens or pests

Abbreviations:

As for Roman numbers and "graft" or "aphids" and phenotype testing - see footnote to Fig. 1.;

$R \boldsymbol{y}-\boldsymbol{F}_{\text {sto }} \quad$ - the gene confers extreme resistance to PVY. The selective marker was described by Flis et al., (2005)

$\boldsymbol{R} \boldsymbol{m}$ - the gene confers hypersensitive resistance to PVM. The identified marker was described by Mar-

czewski et al.,(2006), however the presence of marker(s) is not always related with resistance reaction (Tatarowska et al., 2016);

$N s_{a d g} \quad-$ the gene conferring hypersensitive resistance to PVS. The marker was described by Marczewski et al. (2002);

Rpi-phu1 - the gene confers resistance to P. infestans. The marker phu6 was described by Śliwka et al. (2013);

$\boldsymbol{H} \mathbf{1}$ - the gene confers resistance to pathotype Roland Ro4 of G. rostochiensis. The markers used for identification of resistant potato genotypes were investigated and modified as described by Milczarek et al. (2011). The issues related to practical use of these markers were described by Milczarek et al. (2014). 


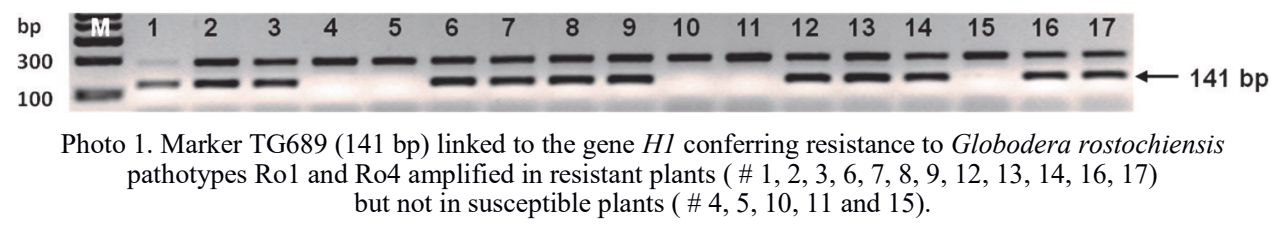

\section{ACKNOWLEDGMENTS}

This work was supported by the Ministry of Agriculture and Rural Development of Poland, Multiannual program "Creating the scientific basis for biological progress and the protection of plant genetic resources as source of innovation and support for sustainable agriculture and food security of the country" Task 2.5. Exploitation of Solanaceae biodiversity for improving traits of potato S. tuberosum L. destined for various cultivation systems and specific purposes.

\section{REFERENCES}

Brylińska M., Śliwka J. 2017. Laboratory assessment of potato resistance to Phytophthora infestans. Plant Breed. and Seed Sci. 76: 17-23.

Chrzanowska M., Sieczka M.T., Zagórka H. 2002. Resistance to PVM in potato parental lines bred in Młochów Research Center, IHAR. Plant Breed. Seed Sci. 46 (2): 57-65.

Chuquillanqui C., Jones R.A.C. 1980. A rapid technique for assessing the resistance of families of potato seedlings to potato leaf roll virus. Potato Res. 23: 121-128.

Davidson T.M.W. 1973. Assessing resistance to leafroll virus in potato seedlings. Potato Res. 16: 99-108.

EPPO/OEPP. 2006. Phytosanitary procedures: Testing of potato varieties to assess resistance to Globodera rostochiensis and Globodera pallida. Bull.OEPP/EPPO Bull. 36: 419-420.

Flis B., Hennig J, Strzelczyk-Żyta D, Gebhardt C, Marczewski W. 2005. The Ry-fsto gene from Solanum stoloniferum for extreme resistant to Potato virus Y maps to potato chromosome XII and is diagnosed by PCR marker GP122718 in PVY resistant potato cultivars. Mol. Breed. 15: 95-101.

Flis B., Wasilewicz-Flis I. 1998. Progeny tests to identify diploid potato clones homozygous at loci controlling resistance to PLRV. Potato Res. 41: 219-228.

Marczewski W., Hennig J., Gebhardt C. 2002. The Potato virus S resistance gene Ns maps to potato chromosome VI. Theor. Appl. Genet. 105: 564-567.

Marczewski W., Ostrowska K., Zimnoch-Guzowska E. 1998. Identification of RAPD markers linked to the Ns locus in potato. Plant Breed. 117: 88-90.

Marczewski W., Strzelczyk-Żyta D., Hennig J., Witek K., Gebhardt C. 2006. Potato chromosomes IX and XI carry genes for resistance to potato virus M. Theor. Appl. Genet. 112: 1232-1238.

Milczarek D., Flis B., Przetakiewicz A. 2011: Suitability of molecular markers for selection of potatoes resistant to Globodera spp. American Journal of Potato Research 88: 245-255.

Milczarek D., Przetakiewicz A., Kamiński P., Flis B. 2014. Early selection of potato clones with H1 resistance gene - the relation of nematode resistance to quality characteristics. Czech J. Genet. Plant 50: 278-284.

Parental line breeding and selection in potato breeding. Proceedings of the Join Conference of the EAPR Breeding Section and the EUCARPIA Potato Section, Wageningen, The Netherlands, 1988.

Plich J., Tatarowska B., Milczarek D., Zimnoch-Guzowska E., Flis B. 2016. Relationships between racespecific and race-non-specific resistance to potato late blight and length of potato vegetation period in various sources of resistance. Field Crops Res. 196: 311-324.

Przetakiewicz J. 2009. Propozycja zmian w polskiej skali oceny odporności odmian ziemniaka na raka ziemniaka zgodnie z Protokołem Diagnostycznym EPPO PM 7/28. Suggestions for changes in the Polish scale used to evaluate the resistance of potato cultivars to potato wart disease according to the EPPO Diagnostic Protocol PM 7/28. Biul. Instytutu Hodowli i Aklimatyzacji Roślin 254: 169-177.

Syller J. 1087. The influence of temperature on transmission of potato leafroll virus by Myzus persicae Sulz. Potato Res. 30: 47-58.

Syller J. 1988. Detection of potato leafroll virus in intact sprouts disks by Enzyme-linked Immunosorbent Assay. J. Phytopathol. 121: 58-64. 
Śliwka, J., Świątek, M., Tomczyńska, I., Stefańczyk, E., Chmielarz, M. and Zimnoch-Guzowska, E. 2013. Influence of genetic background and plant age on expression of the potato late blight resistance gene Rpi -phul during incompatible interactions with Phytophthora infestans. Plant Pathol. 62: 1072-1080.

Świeżyński K.M., Zimnoch-Guzowska E. 1996. Development of parental lines for Polish potato breeding. J. Appl. Gen. 37A: 15-23.

Świeżyński K.M., Dziewońska M.A., Ostrowska K. 1981. Inheritance of resistance to potato virus M fund in Solanum gourlayi Haw. Genet. Pol. 22: 1-8.

Tatarowska B., Milczarek D., Plich J., Flis B. 2016 Reakcja na wirus M ziemniaka (PVM) tetraploidalnych rodów ziemniaka. Biuletyn Instytutu Hodowli i Aklimatyzacji Roślin 280: 23-33 (in Polish with English abstract)

Valkonen J.P. 1994. Natural genes and mechanisms for resistance to viruses in cultivated and wild potato species (Solanum spp.). Plant Breed. 112: 1-16.

Wiersema H.T. 1972. Breeding for resistance. In: Viruses of potatoes and seed-production. Ed. De Bokx J.A., Wageningen 174-187.

Zarzycka H. 1990. A comparison of tuber slice and whole tuber tests for the assessment of potato resistance to tuber blight (Phytophthora infestans (Mont.) de Bary). Acta Agrobot. 43 (1): 95-107.

Zimnoch-Guzowska E., Chrzanowska M., Yin Z., Flis B. 2013. Sources and Effectiveness of Potato PVY Resistance in IHAR's Breeding Research. Am. J. Potato Res. 90 (1): 21-27. 